\title{
PENERAPAN INLIS Lite (INTEGRATED LIBRARY SYSTEM) DI KANTOR PERPUSTAKAAN DAN ARSIP DAERAH KABUPATEN PANGKEP, SULAWESI SELATAN
}

\begin{abstract}
Abdul Hamid*
Pengutipan: Hamid, A., (2015). Penerapan INLIS lite (Integrated Library System) di Kantor Perpustakaan dan Arsip Daerah Kabupaten Pangkep, Sulawesi Selatan. Jurnal Ilmu Perpustakaan, Informasi, dan Kearsipan Khizanah Al-Hikmah, 3(2), 112-124.

* Kepala Perpustakaan SMA Negeri 2 Liukang Kalukuang Masalima (Kalmas), Kepulauan Pangkep, Sulawesi Selatan
\end{abstract}

\begin{abstract}
ABSTRAK
Teknologi komunikasi dan informasi (TIK) telah merambah ke berbagai bidang kehidupan masyarakat dunia. Kemudahan yang ditawarkan oleh alat-alat teknologi tersebut bervariatif menyesuaikan dengan kebutuhan para penggunanya. Kantor Perpustakaan dan Arsip Daerah (KPAD) Kabupaten Pangkep telah menerapkan TIK dalam meningkatkan kinerja layanannya kepada masyarakat Kabupaten Pangkep. INLIS lite menjadi sistem yang digunakan. Penelitian ini berusaha untuk menggambarkan bagaimana penerapan INLIS lite di KPAD Kabupaten Pangkep, kendala-kendala dalam penerapannya, dan juga layanan perpustakaan keliling yang merupakan salah satu bentuk layanan KPAD Kabupaten Pangkep. Penelitian ini merupakan penelitian deskriptif kualitatif. Data yang diperoleh melalui wawancara dengan pustakawan KPAD Kabupaten Pangkep, beberapa masyarakat dan juga siswa-siswi yang ada di kepulauan. Hasil penelitian menunjukkan bahwa INLIS lite belum diterapkan secara optimal dikarenakan beberapa faktor. Kendala utama dalam penerapannya yaitu SDM dan anggaran. Perpustakaan keliling memiliki manfaat yang besar namun jangkauan layanan masih terbatas karena beberapa faktor.
\end{abstract}

Kata kunci : INLIS lite, perpustakaan terapung, Automasi perpustakaan

\section{ABSTRACT}

Information and communication technology (ICT) has been undoubtly applied in all fields of life. It provides variety of services in which it is dependent on user needs. The Kantor Perpustakaan dan Arsip Daerah (the District Library and Archieve of Pangkep) has been implementing ICT to enhance its services to the citizens of Pangkep. INSLISLite was choosen as its automted library system. The current study investigates how INLIS lite has been implemented in the library, what were the challanges the library faced, and the floating library services of KPAD. The data were collected throughout the representative informans. The study found that INLIS lite needed to be more optimized, the challanges were human resources and budgetary, and the floating library has played important roles to educate the Pangkep island citizens.

Key words: INLIS lite, floating library, library automation 


\section{PENDAHULUAN}

Di era teknologi informasi saat ini, masyarakat merasakan kemudahan untuk mengakses informasi yang mereka inginkan. Sebuah motto perusahan telekomunikasi di tanah air "bumi dalam genggaman anda" merupakan hal yang nyata, karena memang tidak dapat dipungkiri lagi bahwa berita- berita atau peristiwa-peristiwa yang ada di setiap belahan dunia sudah sangat mudah untuk diketahui.

Masyarakat dunia yang telah terbiasa dengan alat-alat teknologi komunikasi dan informasi tentu memiliki keunggulan tersendiri dalam mengakses informasi. Di banyak instansi di setiap negara ada yang telah dan ada pula yang baru menerapkan berbagai macam aplikasi dan sarana yang membantu para pekerja mereka untuk mengakses informasi, setidaknya yang berkaitan dengan lingkungan tempat kerja mereka.

Sebagaimana yang diketahui banyak orang bahwa informasi, karena ia dibutuhkan maka ia merupakan hal yang sangat penting. Setiap instansi/lembaga tentu membutuhkan yang namanya informasi. Sebagai contoh, lembaga yang disebut perpustakaan, yang memang perannya untuk mengelola informasi, di era saat ini dituntut untuk mengelola informasi sesuai dengan kondisi zaman saat ini. Maksudnya, yaitu agar pengelolaan informasi di setiap perpustakaan yang ada juga harus menerapkan media teknologi komunikasi dan informasi yang tepat.

Jika merujuk ke Undang-Undang Nomor 43 Tahun 2007 tentang Perpustakaan, disebutkan bahwa perpustakaan merupakan pusat informasi yang di dalamnya menghimpun, mengolah dan menyebarkan informasi kepada masyarakat. Lebih spesifik mengenai peran perpustakaan pada Bab 1 Pasal 3 UU yang sama disebutkan bahwa perpustakaan berfungsi sebagai wahana pendidikan, penelitian, informasi dan rekreasi untuk meningkatkan, mencerdaskan dan keberdayaan bangsa (Republik Indonesia, 2007: 4).

Sebagai wahana informasi, maka sebaiknya perpustakaan sudah menerapkan sistem informasi yang handal dengan menerapkan alat-alat teknologi dan informasi untuk mendukung dan memudahkan bagi para pustakawan khususnya dan pemustaka luas pada umumnya dalam hala pengolahan transaksi harian, operasional, manajerial, kegiatan strategis, hingga ke bentukbentuk laporan (Jogiyanto, 2005: 3).

Mengenai sistem informasi yang ideal, Alter (Alter, 1992) mengemukakan bahwa sistem informasi adalah kombinasi antara prosedur kerja, informasi, dan teknologi informasi yang diorganisasikan untuk mencapai tujuan dalam sebuah organisasi. Definisi ini menggambarkan adanya interaksi antara elemen-elemen terikat yang secara sistematis dan teratur untuk menciptakan dan pembentukan aliran informasi yang mendukung pengambilan keputusan dan melakukan kontrol jalannya perpustakaan.

Perpustakaan harus menerapan teknologi informasi sebagai pendukung perkembanagn perpustakaan, sehingga dapat di fungsikan dalam berbagai bentuk salah satunya yaitu sebagai sistem otomasi perpustakaan. Di bidang pekerjaan yang dapat diintegrasikan dengan sistem informasi perpustakaan yaitu pengadaan, inventarisasi, katalogisasi, sirkulasi, pengelolaan anggota, dan sebagainya fungsi ini 
diistilahkan sebagai otomasi perpustakaan.

Kantor Perpustakaan dan Arsip Daerah (KPAD) Kabupaten Pangkep adalah salah satu instansi peggerak maju mundurnya pendidikan di kabupaten ini. Kantor ini telah melaksanakan kegiatan operasionalnya sejak tanggal 05 September 2008 dengan mengembang visi dan misi yang menjadikan perpustakaan sebagai sarana informasi dan sumber ilmu pengetahuan menuju masyarakat yang cerdas dan sejahtera.

KPAD Kabupaten Pangkep telah menerapak sistem informasi untuk mempermudah dalam pengelolaan dan penyimpanan data yang dapat menghasilkan suatu informasi yang tepat dan akurat. Adanya sistem informasi yang tepat dan akurat dapat mengurangi terjadinya kesalahan yang tidak diinginkan sehingga meningkatkan kinerja yang lebih efisien dalam kecepatan operasional instansi.

Berdasarkan observasi awal peneliti, perpustakaan ini telah menggunakan INLIS lite. Namun demikian, dalam penerapan sistem tersebut belum berjalan sesuai apa yang diharapkan karena diakibatkan beberapa faktor di antaranya SDM yang dimiliki (staf/pustakawan) kurang memahami tentang teknologi informasi, sehingga sistem tersebut belum dapat dioptimalkan bahkan masih ada kecenderungan untuk bekerja secara konvensional, sebagai contoh dalam penelusuran informasi di rak buku, yang masih menggunakan kartu katalog.

Tentu menjadi hal yang menarik untuk dikaji yaitu, ketika penerapan teknologi yang ada belum dapat dioptimalkan di kantor perpustakaan tersebut. Melihat kenyataan tersebut tentu menjadikan kendala bagi perpustakaan, apalagi bahwa KPAD Kabupateng Pangkep merupakan salah satu instansi penggerak maju mundurnya pendidikan di Kabupaten Pangkep.

\section{RUMUSAN MASALAH}

Dari uraian singkat di atas, maka peneliti merumuskan beberapa masalah yang hendak untuk dicari tahu, yaitu sebagai berikut:

a. Bagaimanakah penerapan sistem informasi INLIS di Kantor Perpustakaan dan Arsip Daerah Kabupaten Pangkep?

b. Apa saja kendala yang dihadapi pustakawan dalam menerapkan sistem informasi INLIS di Kantor Perpustakaan dan Arsip Daerah Kabupaten Pangkep?

c. Bagaimana sistem informasi layanan Perpustakaan Terapung di Kantor Perpustakaan dan Arsip Daerah Kabupaten Pangkep?

\section{TUJUAN DAN MANFAAT PENELITIAN}

a. Tujuan Penelitian

Adapun tujuan yang hendak penulis capai dalam penelitian ini adalah untuk mengetahui sistem informasi apa yang digunakan oleh Kantor Perpustakaan dan Arsip Kabupaten Pangkep.

1) Untuk mengetahui penerapan sistem informasi di Kantor Perpustakaan dan Arsip Daerah Kabupaten Pangkep.

2) Untuk mengetahui kendala yang dihadapi pustakawan tentang sistem informasi di Kantor Perpustakaan dan Arsip Daerah Kabupaten Pangkep.

3) Untuk mengetahui sistem layanan perpustakaan terapung di Kantor 
Perpustakaan dan Arsip Daerah Kabupaten Pangkep.

\section{b. Manfaat Penelitian}

Adapun manfaat teoritis dari penelitian ini adalah untuk menambah khazanah kajian ilmu perpustakaan, khususnya mengenai sistem informasi di Kantor Perpustakaan dan Arsip Daerah Kabupaten Pangkep serta sebagai rintisan dan bahan perbandingan dalam rangka pengembangan penelitian berikutnya.

Dari sisi pragmatis, penelitian tentang sistem informasi di Kantor Perpustakaan dan Arsip Daerah Kabupaten Pangkep ini diharapkan dapat menjadi pijakan dalam merumuskan kebijakan dalam kerangka pendidikan dan pengembangan institusi pada masa yang akan datang serta akan memberikan manfaat baik bagi peneliti, praktisi, akademisi, pengguna dan juga lembaga perpustakaan.

\section{TINJAUAN TEORETIS}

Berdasarkan hasil yang penulis temukan, terdapat beberapa literatur yang berkaitan dengan pembahasan yang mengkaji tentang sistem informasi di Kantor Perpustakaan dan Arsip Daerah Kabupaten Pangkep antara lain:

\section{a. Manajemen Informasi Perpustakaan Terintegrasi}

Telah banyak perpustakaan yang ada saat ini menerapkan sistem integrasi perpustakaan. Tidak lain maksudnya ialah untuk meningkatkan kinerja layanan perpustakaan-perpustakaan tersebut. Perlunya dirasakan sistem yang dapat memadukan antara tiap-tiap bagian yang ada di sebuah perpustakaan agar bagianbagian tersebut dapat bersinergi dengan visi utama sebuah perpustakaan.
Sistem integrasi perpustakaan, atau kadang disebut dengan sistem otomasi perpustakaan, yang dalam istilah asingnya (Integrated Library System) merupakan sebuah kesatuan yang terdiri dari bagian-bagian yang saling terkait satu sama lain untuk bersama-sama bekerja mencapai tujuan utama sebuah lembaga atau organisasi, dalam hal ini yaitu tujuan perpustakaan itu sendiri.

\section{b. INLIS lite}

INLIS lite merupakan perangkat lunak (software) aplikasi otomasi perpustakaan yang dibangun dan dikembangkan oleh Perpustakaan Nasional Republik Indonesia (Perpusnas) sejak tahun 2011. Penamaan INLIS diambil dari kata Integrated Library System, nama dari perangkat lunak manajemen informasi perpustakaan terintegrasi yang dibangun sejak tahun 2003 untuk keperluan kegiatan rutin pengelolaan informasi perpustakaan di internal Perpusnas.

Seiring dengan perkembangan dunia perpustakaan, khususnya di Indonesia, Perpusnas memandang perlu untuk memfasilitasi semangat pengelola perpustakaan di seluruh daerah untuk memulai menerapkan otomasi perpustakaan menuju terwujudnya perpustakaan digital, maka Perpusnas berinisiatif untuk mendistribusikan perangkat lunak ini dalam versi yang lebih ringan dengan nama INLIS Lite.

INLIS Lite merupakan inisiatif Perpusnas dalam rangka penyediaan sarana pendukung untuk :

membantu pengembangan otomasi perpustakaan di seluruh Indonesia,

Sebagai tool perpustakaan digital untuk mengelola koleksi full teks dan multimedia, 
Mmembantu dalam pembentukan katalog elektronis berbasis MARC untuk Indonesia (INDOMARC).

melaksanakan program nasional yang diamanatkan kepada Perpusnas untuk menghimpun data koleksi nasional dalam sebuah Katalog Induk Nasional (KIN) dan Bibliografi Nasional Indonesia (BNI) dengan memanfaatkan teknologi informasi dan komunikasi.

$>$ membantu pembentukan Katalog Induk Daerah (KID) dan Bibliografi Daerah (BiD) yang diselenggarakan oleh perpustakaan umum provinsi bersama mitra kerjanya di tingkat kabupaten dengan memanfaatkan teknologi informasi dan komunikasi (http://inlislitev2.perpusnas.go.id/)

\section{c. Perpustakaan Terapung}

Tertuang dalam Undang-Undang Nomor 43 Tahun 2007 Tentang Perpustakaan Bab III Pasal 22 Ayat (5) yang berbunyi "Pemerintah, pemerintah provinsi, dan/atau kabupaten/kota melaksanakan layanan perpustakaan keliling bagi daerah yang belum terjangkau oleh layanan perpustakaan menetap."

Amanah yang tertuang dalam UU di atas perlu mendapat perhatian khusus bagi perpustakaan umum, yang dalam hal ini KPAD Kabupaten Pangkep agar dapat memperhatikan masyarakatnya yang memang sebagian tinggal di daerahdaerah kepulauan wilayah tersebut.

Pada Penjelasan Atas Undang-undang Republik Indonesia Nomor 43 Tahun 2007 Tentang Perpustakaan pada Pasal 5 Ayat (2) menyatakan bahwa "Masyarakat daerah terpencil, terisolasi atau terbelakang akibat faktor geografis berhak mendapatkan layanan perpustakaan sesuai dengan kondisi setempal misalnya, perpustakaan keliling atau perpustakaan terapung."
Perpustakaan keliling adalah bagian dari perpustakaan umum yang mendatangi pemakai dengan menggunakan kendaraan (darat maupun air), secara umum perpustakaan keliling berfungsi sebagai perpustakaan umum yang melayani masyarakat yang tidak terjangkau oleh perpustakaan umum (menetap) (Sulistyo-Basuki: 1991).

Pengertian lainnya (Supriyanto: 2006) menyatakan bahwa perpustakaan keliling adalah perpustakaan yang bergerak (mobile library) dengan membawa bahan pustaka seperti buku, majalah, koran, dan bahan pustaka lainnya untuk melayani masyarakat dari satu tempat ke tempat lain yang belum terjangkau oleh layanan perpustakaan umum kotamadya yang menetap.

\section{METODOLOGI PENELITIAN}

\section{a. Jenis dan Pendekatan Penelitian}

Penelitian ini merupaka penelitian deskriptif dengan pendekatan kualitatif. Penelitian deskriptif mendiskripsikan gambaran atau lukisan secara sistematis, faktual dan akurat mengenai fakta-fakta, sifat-sifat hubungan antara fenomena yang diselidiki. Metode kualitatif yaitu dimana diusahakan untuk mencari gambaran dan penjelasan mengenai permasalahan yang dibahas (Sugiyono, 2010: 14)

\section{b. Sumber Data}

Data Primer, merupakan data yang diproleh dari pustakawan, kepala perpustakaan, dan Kantor Perpustakaa dan Arsip Daerah Kabupaten Pangkep dengan memberikan sejumlah pertanyaan sebagai instrument penelitian 
Data Sekunder, yaitu data yang diproleh untuk melengkapi data primer berupa dokumen-dokumen atau laporan yang dapat mendukung pembahasan dalam kaitannya dengan penelitian ini.

\section{c. Teknik Pengumpulan Data}

Pengumpulan data adalah cara-cara untuk memperoleh data-data yang lengkap, objektif dan dapat dipertanggung jawabkan kebenarannya sesuai dengan permasalahan penelitian yang berkaitan dengan persepsi masayarakat tentang ketersediaanya sistem informasi dengan kebutuhan informasi di Kantor Perpustakaan dan Arsip Daerah Kabpaten Pangkep.

Adapun teknik pengumpulan data yang digunakan dalam penelitian ini adalah:

Observasi, merupakan suatu proses yang kompleks, suatu proses yang tersusun dari berbagai proses (Sutrisno, 2010: 310). Adapun pengertian lain tentang observasi. Observasi adalah melakukan pencatatan secara sistematik kejadian-kejadian, perilaku, obyek-obyek yang dilihat dan hal-hal lain yang diperlukan dalam mendukung penelitian yang sedang dilakukan (Sarwono, 2006: 224).

Wawancara, adalah pertemuan dua orang untuk bertukar informasi dan ide melalui tanya jawab, wawancara langsung atau bertatap muka terhadap informan agar menjawab pertanyaanpertanyaan lisan maupun tulisan yang berkaitan dengan objek penelitian (Sugiyono 2010:217).

Dokumentasi, yaitu cara mengetahui sesuatu dengan melihat catatan-catatan, arsip-arsip, dokumen-dokumen yang berhubungan dengan informasi yang di butuhkan dalam penelitian.

\section{d. Instrumen Penelitian}

Yang dimaksud dengan instrumen penelitian adalah alat yang digunakan dalam melaksanakan penelitian yang sesuai dengan metode yang digunakan. Adapun instrumen yang digunakan peneliti dalam mengumpulkan data antara lain:

Pedoman wawancara, adalah proses tanya jawab dalam penelitian yang berlangsung secara lisan di mana wawancara tersebut dilakukan terhadap responden yang dianggap mampu memberikan data tentang apa yang sedang diteliti dengan menggunakan alat tape recorder.

Kamera, alat yang digunakan untuk mendokumentasikan data penelitian berbentuk gambar.

Tape Recorder, digunakan untuk merekam saat wawancara berlangsung.

\section{e. Teknik Analisis dan Pengolahan Data}

Data yang telah terkumpul akan mempunyai arti setelah diolah dan dianalisa dengan menggunakan beberapa tekhnik deskriptif kualitatif dalam bentuk naratif yaitu hasil data observasi, wawancara, dan dokumentasi terebut dianalisa data kualitatif deskriptif adalah sebagai berikut.

Reduksi data yaitu data yang diperoleh dari lapangan yang banyak dan kompleks maka perlu dilakukan analisis data melalui reduksi data. mereduksi data dengan cara merangkum, memilih hal-hal pokok, memfokuskan hal-hal yang penting dan membuang hal-hal yang dianggap kurang penting. Dengan demikian data yang direduksi dapat memberi gambaran yang jelas bagi penulis untuk mendapat data selanjutnya. 
Penyajian data yaitu data yang sudah direduksi disajikan dalam bentuk uraian singkat berupa teks yang bersifat naratif. Melalui penyajian data tersebut maka data akan mudah dipahami sehingga memudahkan rencana kerja selanjutnya.

Selanjutnya yaitu penarikan kesimpulan. Data yang sudah disajikan dianalisis secara kritis berdasarkan faktafakta yang diperoleh dilapangan. penarikan kesimpulan dikemukakan dalam bentuk naratif sebagai jawaban dari rumusan masalah yang dirumuskan sejak awal.

\section{HASIL PENELITIAN DAN PEMBAHASAN}

Kabupaten Pangkep adalah kabupaten yang dari letak geografisnya memiliki 2 (dua) wilayah yang sangat luas yaitu daratan dan kepulauan. Karena letak geografis tersebut maka Kantor Perpustakaan dan Arsip Daerah (KPAD) Kabupaten Pangkep menjalankan fungsinya berdasarkan peraturan Daerah No 12 Tahun 2007 tentang organisasi dan tata kerja lembaga teknis pemerintahan kabupaten pangkajene dan kepulauan, yaitu melayani masyarakat di daratan dan kepuluan di wilayah Kabupaten Pangkep.

Dengan memiliki visi yaitu menjadikan perpustakaan sebagai sarana informasi dan sebagai sumber ilmu pengetahuan menuju masyarakat yang cerdas dan sejahtera, KPAD Kabupaten Pangkep tengah dalam proses mengembangkan layanannya kepada masyarakat di kabupaten tersebut. Berikut ini akan dipaparkan hasil penelitian berdasarkan rumusan masalah yang telah disebutkan sebelumnya.

\section{a. Penerapan INLIS lite Di Kantor Perpustakaan dan Arsip Daerah Kabupaten Pangkep}

Sistem informasi merupakan kumpulan elemen-elemen yang saling berkaitan satu sama lain. Jika terdapat sebuah elemen yang tidak berjalan dengan baik, maka akan berdampak pada kinerja sistem itu sendiri. Kantor Perpustakaan dan Arsip Daerah (KPAD) Kabupaten Pangkep merupakan kabupaten yang terdaftar dalam penerima bantuan pengembangan aplikasi INLIS lite tahap II dari Perpustakaan Nasional RI. Dari 153 Kabupaten, Perpustakaan Umum Kabupaten memanfaatkan perangkat keras otomasi perpustakaan INLIS lite pada tahun 2011.

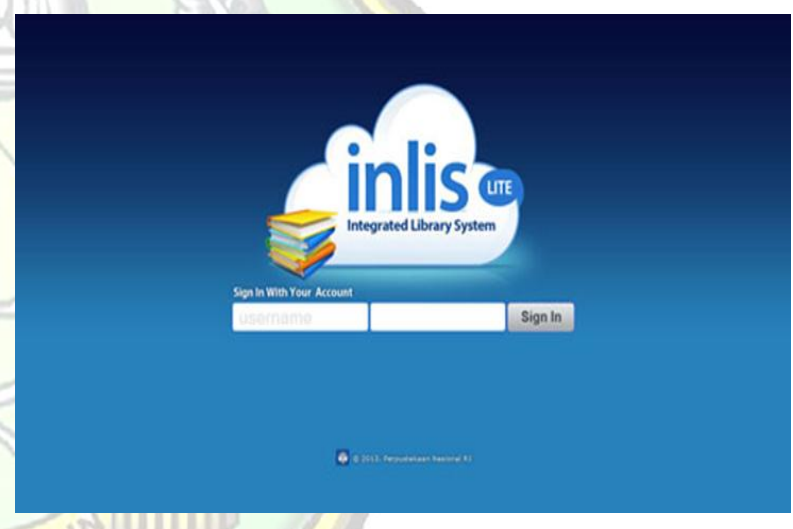

(Sumber: KPAD Kab. Pangkep)

Gambar 1. Halaman Login INLIS lite

Integrated Library Information System (INLIS) lite atau sistem perpustakaan terintegrasi digunakan KPAD Kabupaten Pangkep sejak tahun 2011 dengan tujuan mempermudah para staf atau pustakawan dalam mengembangkan perpustakaan dan memperpudah bagi para anggota pemustaka atau masyarakat kabupaten pangkep.

Namun, berdasarkan hasil wawancara dengan salah seorang petugas KPAD 
Kabupaten Pangkep bahwa penerapan sistem ini hanya berlangsung dalam waktu yang sangat singkat (sekitar satu minggu saja) dikarenakan satu-satunya operator yang dipercaya mengoperasikan sistem tersebut meninggal dunia. Dalam waktu yang relatif singkat tersebut, dengan jumlah koleksi perpustakaan sekitar 7.908 judul, data yang kami peroleh di dalam sistem INLIS lite tersebut hanya berjumlah 6 judul saja.

Penyebab ini mengakibatkan layanan di KPAD Kabupaten Pangkep kembali menerapkan sistem manual dalam memberikan informasi serta dalam pencarian informasi di rak dengan menggunakan kartu katalog, meski beberapa telah menggunakan teknologi seperti dalam pembuatan kartu anggota, katalog, label buku dan yang lainya.

Namun sangat disayangkan karena aplikasi INLIS lite ini tidak berjalan atau berfungsi sebagaimana yang diharapkan para pustakawan dan juga pemustaka pada umumnya. Akan tetapi, berdasarkan hasil wawancara dengan kepala perpustakaan bahwa perpustakaan telah berinisiatif untuk mengaktifkan kembali aplikasi INLIS lite ini dangan menyarankan para pustakawan yang bertugas khususnya di bagian pengolahan bahan pustaka dan pelayanan mempelajari sistem tersebut, dan tentu saja diharapkan semua pustakawan memahami sistem tersebut.

Sistem INLIS lite yang disumbangkan Perpustakaan Nasional Republik Indonesia (Perpusnas) kepada KPAD Kabupaten Pangkep ini diharapkan mampu bersahabat atau bekerja sama dengan perpustakaan kabupatenkabupaten kota lainya yang menerapkan aplikasi yang sama khususnya kabupaten/kota yang berada di Sulawesi- selatan agar dapat mengembangkan perpustakaan yang lebih bersinerjik dengan teknologi informasi di era modern saat ini.

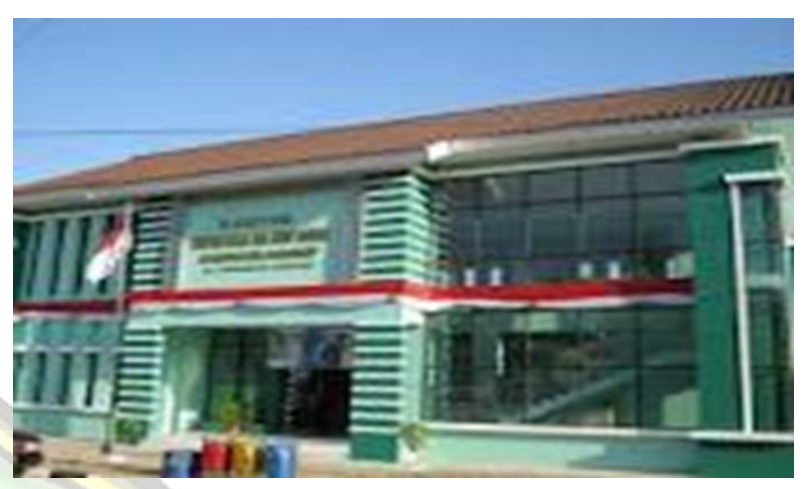

Gambar 2. Gedung KPAD Kab. Pangkep

\section{b. Kendala-Kendala Yang Dihadapi Dalam Penerapan Sistem Informasi INLIS Di Perpustakaan Kabupaten Pangkep}

Kendala merupakan bagian yang lumrah pada setiap instasi/lembaga, begitu pula di perpustakaan, khususnya dalam usaha mengembangkan atau meningkatkan layanannya. Berikut ini akan dikemukakan hasil wawancara mengenai kendala-kendala yang dihadapi oleh KPAD Kabupaten Pangkep dalam menerapkan sistem tersebut.

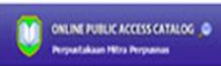

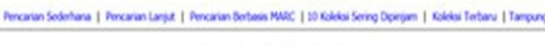

Pencarian Tinglot Lanjut

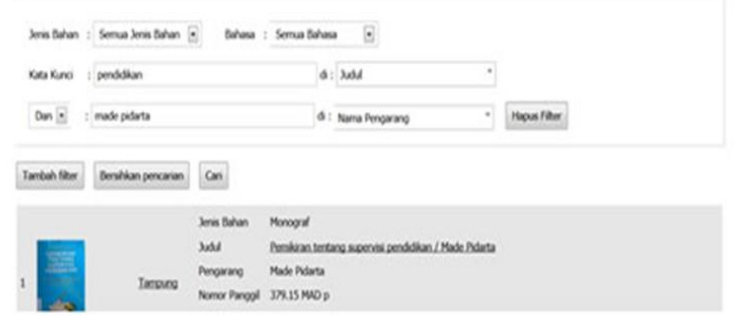

Gambar 3. OPAC perpustakaan 


\section{1) Keterbatasan SDM (Sumber Daya 2) Anggaran \\ Manusia)}

Sumber daya manusia di KPAD Kabupaten Pangkep menjadi kendala utama dalam penerapan sistem tersebut, khususnya mereka yang memiliki skil mengenai alat-alat teknologi komunikasi dan informasi. Sebagaimana dapat dicatat bahwa meskipun beberapa pustakawan bisa mengoprasikan teknologi informasi tapi mereka kurang mahami tentang aplikasi INLIS lite tersebut yang diterapkan perpustakaan.

Sebagaimana yang telah dikemukakan sebelumnya bahwa hanya ada satu orang pustakawan saja di KPAD Kabupaten Pangkep yang memahami dan mengoperasikan aplikasi INLIS. Keterbatasan pemahaman pada sistem ini sangat berimplikasi pada kinerja perpustakaan. Pustakawan dan pemustaka bahkan belum dapat menikmati kemudahan-kemudahan yang ditawarkan oleh aplikasi INLIS seperti OPAC bagi pemustaka, yang memiliki keintegrasian dalam kegiatan perpustakaan yang meringankan pekerjaan rutin pustakawan.

Itulah sebabnya mengapa keterbatasan tenaga pustakwan menjadi kendala utama dalam memanfaatkan sistem informasi INLIS di Kantor Perpustakaan dan Arsip Daerah Kabupaten Pangkep. Selain itu, kendala ini juga berimplikasi pada minimnya kreatifitas pustakawan dalam mengolah perpustakaan sehingga sulit menggandengkan visi perpustakaan pada era yang serba teknologi saat ini. Perpustakaan yang terus dipaksa mampu bersinerjik dengan teknologi.
Biaya penerapan sistem tersebut juga merupakan kendala bagi KPAD Kabupaten Pangkep. Meskipun merupakan sumbangan dari PERPUSNAS, namun perlu diingat akan perlunya biaya dalam menerapkan sistem tersebut. Dari pengadaan alat-alat hingga pelatihan operator yang dapat menerapkannya, serta biaya khusus untuk perbaikan atau pemeliharaan yang apabila sistem tersebut mengalami kendala.

Seperti yang telah dikemukakan sebelumnya bahwa sebuah sistem informasi saat ini yaitu mengintegrasikan antara perangkat-perangkat kerat, lunak, dan juga sumber daya manusia yang terampil. Dalam hal perangkat keras (hardware) tentu tidaklah mudah mengadakannya jika tidak memiliki pemahaman mengenai alat-alat teknologi atau komputer.

Demikian pula dengan perangkat lunak (software) INLIS lite. Sistem ini memerlukan orang yang terlatih dalam menerapkannya. Selain itu, juga tahu mengatasi masalahnya apabila di suatu saat nanti mengalami kendala. Namun demikian, menarik untuk dicatat di sini bahwa KPAD Kabupaten Pangkep telah berinisiatif untuk menerapkan dan mengoptimalkan kembali sistem INLIS lite tersebut.

\section{3) Perpustakaan Terapung KPAD Kabupaten Pangkep}

Kabupaten pangkep merupakan kabupaten yang memiliki wilayah yang sangat luas mulai dari darat, pesisir dan kepulauan. Sebagai kabupaten yang juga memiliki wilayah yang terdiri dari berbagai kepulauan dan memiliki 
penduduk cukup banyak, maka sepantasnya KPAD Kabupaten Pangkep juga memberikan layanannya kepada masyarakat-masyarakat yang ada di setiap pulau-pulau yang ada di wilayah ini. Tercatat sejak 15 April 2009 Pustakaan Nasional Republik Indonesia (Perpusnas) memberikan sumbangan satu unit perpustakaan terapung kepada KPAD Kabupaten Pangkep (seperti yang terlihat pada gambar di bawah ini), dengan harapan dapat memberikan pendidikan non formal bagi masyarakat yang berada di kepulauan dan pesisir.

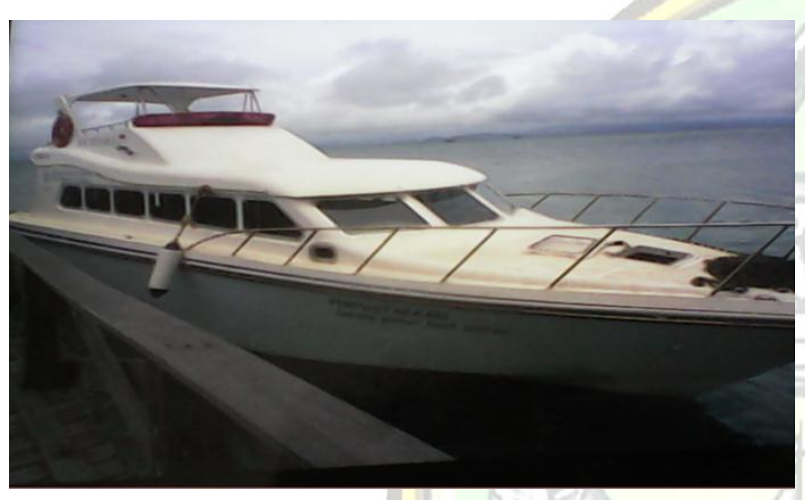

Gambar 4. Perpustakaan terapung KPAD Kab. Pangkep

Namun dalam pengoperasian perpustakaan terapung ini, sejauh ini hanya dilayankan di salah satu kecamatan di wilayah Kabupaten Pangkep sementara kabupaten ini memiliki 4 (empat) kecamatan yang terdiri berbagai pulau di antaranya yaitu Kecamatan Liukang Tupabiring Selatan, Kecamatan Liukang Tupabiring Barat, Kecamatan Liukang Tanggaiya, Kecamatan Liukang Kalmas.

Dari 4 (empat) kecamatan ini hanya Kecamatan Liukang Tupabiring Selatan saja yang bisa dijangkau oleh perpustakaan Terapung Pangkep. Karena kecamatan lainnya memiliki jarak yang sangat jauh dari daratan Kabupaten Pangkep.
Mengingat banyak sekali yang harus dipertimbangkan oleh perpustakaan pada saat beroprasi diberbagai pulau. Di antaranya yaitu biaya bahan bakar minyak, keadaan cuaca, makanan dan penggandaan mesin kapal dan yang lainya.

Dari hasil wawancara, perpustakaan terapung telah menggunakan biaya sebesar 4.000.000 dalam satu kali operasi ke pulau-pulau yang sudah dijadwalkan, perpustakaan terapung hanya menjangkau satu atau dua pulau dalam satu hari mengingat waktu dan biaya yang sangat dipehitungakan dalam melayani masyarakat kepulauan.

Dari informasi yang diperoleh bahwa, perpustakaan terapung saat ini belum bisa kembali beroperasi melayani masyarakat yang ada di kepulauan dikarenakan pada bulan Oktober tahun 2012, perpustakaan terapung telah mengalami kecelakaan di tengah laut yang disebabkan ombak yang sangat besar menghantam kapal tersebut sehingga menyebabkan mesin perpustakaan terapung tersebut rusak diakibatkan masuknya air ke dalam ruang kapal sehingga menyebabkan beberapa koleksi rusak dan basah. Menarik untuk diketahui bahwa, sejak kejadian tersebut pustakawan yang beroperasi pada saat itu telah mengalami trauma yang besar.

\section{1) Layanan Perpustakaan Terapung KPAD Kabupaten Pangkep}

Perpustakaan terapung KPAD Kabupaten Pangkep memberikan jam layanan yaitu siang hari antara pukul $10.30 \mathrm{~s} / \mathrm{d} 14.00$ dengan melihat waktu istirahat siswa-siswi di sekolah dan anggota masyarakat, akan tetapi perpustakaan terapung lebih dominan dimanfaatkan oleh para siswa-siswi 
sekolah jika dibandingkan dengan masyarakat kepulauan atau pesisir.

Pada saat jam istirahat di sekolah tiba, para pustakawan dan guru di sekolah serta siswa-siswi menuju dermaga di mana perpustakaan terapung berada. Siswa- siswi akan dihitung sebanyak 25 dan dipersilahkan masuk untuk memanfaatkan koleksi yang sudah disediakan secara bergantian dengan siswa yang masih menunggu di atas dermaga.

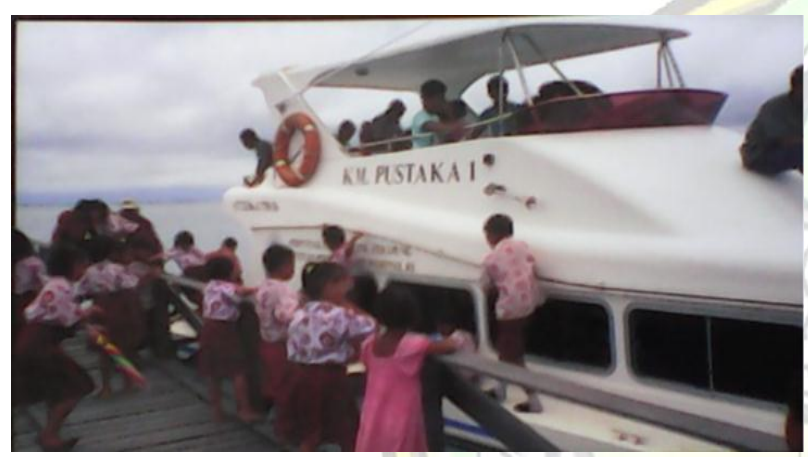

Gambar 5. Para siswa-siswi kepulauan berkunjung ke perpustakaan keliling KPAD Kab. Pangkep

Perpustakaan terapung memberi kebebasan kepada para pemustakanya (pemakainya) untuk dapat masuk dan memilih sendiri koleksi yang di inginkan. Petugas hanya mencatat apabila koleksi tersebut di pinjam serta pada saat dikembalikan.

Keberadaan layanan perpustakaan keliling KPAD kepada masyarakat kepulauan dan pesisir ini tentu memberikan manfaat yang besar, dan bersinergi dengan visi KPAD Kabupaten Pangkep sendiri. Berikut ini kelebihan dan kekurangan layanan perpustakaan keliling.

\section{Kelebihan}

$\checkmark$ Masyarakat kepulaun bebas memilih bahan pustaka yang dibutuhkan langsung pada jajaran koleksi

$\checkmark$ Masyarakat kepulauan dapat memukan koleksi lain yang sesuai atau menarik untuk dibaca.

$\checkmark$ Pemakai dapat langsung mencari alternatif lain dengan subjek yang sama pada jajaran koleksi secara cepat.

$\checkmark$ Tidak memerluka petugas yang banyak untuk melayani pengambila koleksi.

\section{Kekurangan}

Susunan jajaran koleksi menjadi sulit teratur,

$\checkmark$ Kemungkinan bahan pustaka hilang lebih tinggi,

Terjadi kerusakan koleksi

\section{2) Tempat dan Layanan Baca}

Tempat dan layanan baca diberikan kepada pemustaka khususnya para pelajar yang mana memang belum diperbolehkan untuk meminjam buku dikarenakan belum memiliki Kartu Tanda Pengenal (KTP). Mereka dapat membaca buku di ruang baca sesuai tempat yang sudah disiapkan dengan jadwal layanan perpustakaan terapung. Sedangkan pemustaka yang sudah memiliki KTP dapat memanfaatkan layanan $\mathrm{di}$ atas kapal perpustakaan terapung.

Batas peminjaman koleksi perpustakaan terapung menjadi catatan penting di sini. Dari hasil wawancara dengan salah seorang informan bahwa waktu peminjaman dan pengembalian buku yang dinilai sangat singkat, syarat pememinjaman yang hanya bisa diperuntukkan bagi pemustaka yang telah memiliki kartu tanda pengenal seperti $\mathrm{KTP}$, kartu pelajar para siswa. 


\section{KESIMPULAN DAN SARAN}

\section{a. Kesimpulan}

Berdasarkan hasil dan pembahasan dari penelitian yang telah diuraikan serta analisis data, pada bagian ini penelitian ini akan mengemukakan beberapa kesimpulan sebagai berikut.

- KPAD Kabupaten Pangkep menerapkan INLIS lite sebagai sistem informasi/sistem otomasi layanan perpustakaan ini,

- Dalam penerapannya mengalami kendala seperti SDM dan juga anggaran penerapannya,

- Sejak 2009 perpustakaan terapung KPAD telah beroperasi, namun saat ini tidak lagi beroperasi disebabkan kerusakan mesin kapal tersebut

\section{b. Saran}

Penelitian ini dapat memberikan saran atau masukan kepada KPAD Kabupaten Pangkep, yaitu sebagai berikut.

- INLIS lite merupakan sistem yang dapat mendukung kinerja KPAD Kabupaten Pangkep, oleh karena itu sebaiknya dapat dioptimalkan kembali fungsinya,

- Perlunya memperdayakan SDM yang ada, atau menambah SDM guna meningkatkan layanan yang cukup luas yang terdiri dari wilayah daratan dan kepulauan, khususnya skil TIK

- Layanan perpustakaan keliling idealnya mencakup seluruh wilayah kepulauan yang ada di Kabupaten Pangkep

- Alokasi anggaran khusus bagi perpustakaan keliling

\section{DAFTAR PUSTAKA}

Alter, Steven. 1992. Information Systems:A Management Perspectve. The

Benjamin/Cummings Publishing Company, Inc.

(http:/ / inlislitev2.perpusnas.go.id/)

Jogiyanto. 2005. Sistem Teknologi informasi. Andi: Yogyakarta.

Oetomo, Budi Sutedjo Dharma. 2006. Perencanaan dan Pembangunan Sistem Informasi. Andi: Yogyakarta

Pertiwi, Dini Hari. 2011. Desain dan Innplementasi Sistem Informasi Perpustakaan Bersasis Web dengan Model View Controle. Palembang/

Republik Indonesia. 2007 Undang-undang Republik Indonesia tentang Perpustakaan. Cet. III. Perpustakaan Rasional RI: Jakarta:

Sugiyono. 2012. Metode Penelitian Kuantitatif, Kualitatif dan R\&D. Cet. XVII. Alfabeta: Bandung.

Sulistyo-Basuki. 1991. Pengantar ilmu perpustakaan. Gramedia Pustaka Utama: Jakarta.

Supriyanto. 2006. Aksentuasi perpustakaan dan pustakawan. Sagung Seto: Jakarta.

Supriyanto, Wahyu dan Ahmad Muhsin. 2008 Teknologi Informasi Perpustakaan: Stategi Perancangan Perpustakaan Digital. Kanisius: Yogyakarta.

Sutarno NS. 2006 Perpustakaan dan Masyarakat. Cet. I: Yayasan Obor Indonesia: Jakarta.

Sutopo, Hadi Ariesto. 2012. Teknologi Informasi Komonikasi Dalam Pendidikan. Kanisius: Yogyakarta.

Suwarno, Wiji.2010 Dasar-dasar Ilmu Perpustakaan : Sebuah Pendekatan Praktis. Yogyakarta: Ar-Ruzz Media.

2011 Perpustakaan dan

Buku:Wacana Penulisan dan 
Penerbit. Ar-Ruzz media:

Jogyakarta:

Yusup, Pawit M. 2012 Perspektif

Manajemen Pengetahuan

Informasi, Komonikasi, dan

Perpustakaan. Rajawali Pers:

Jakarta.

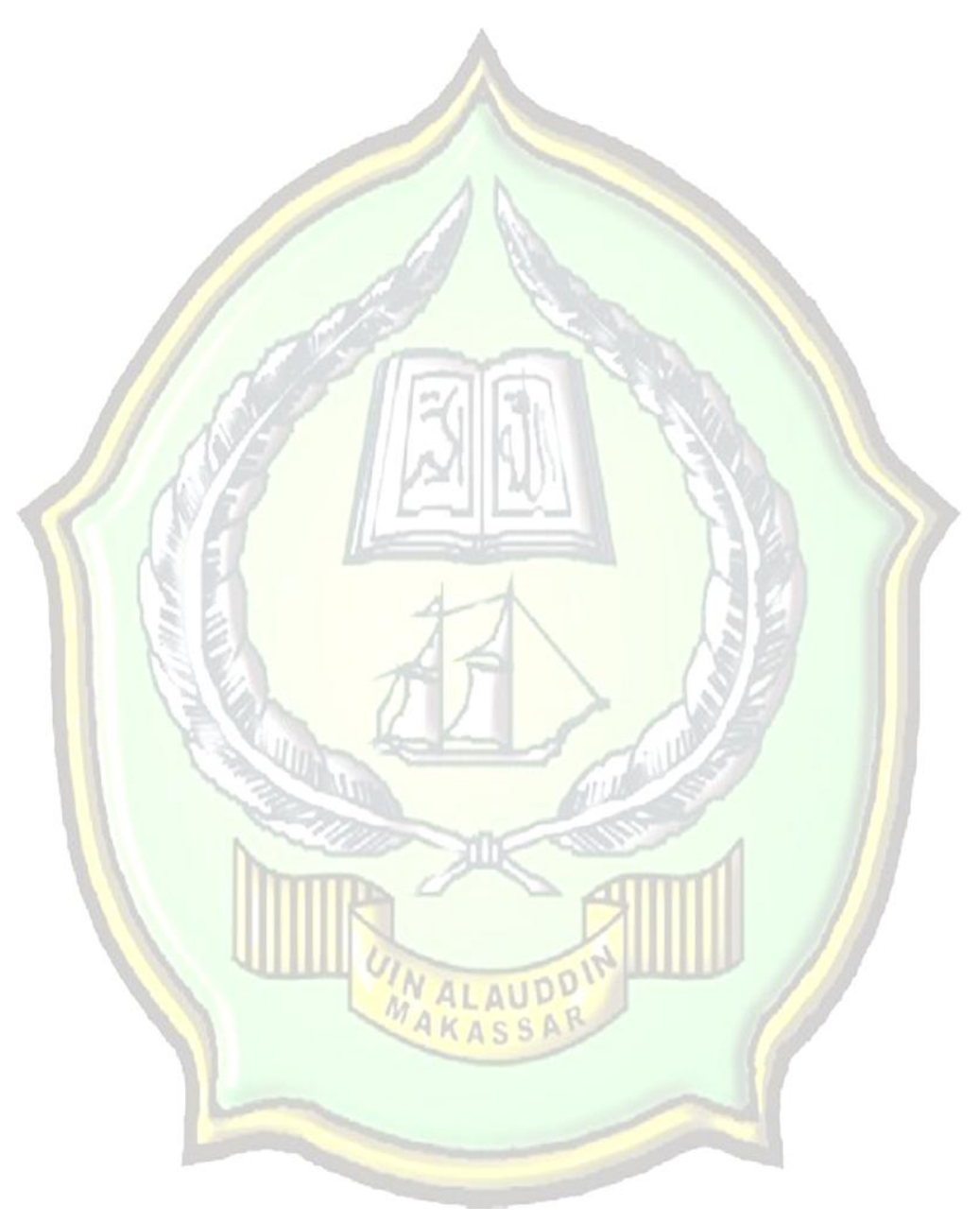

